\title{
Analysis of the profitability of a photovoltaic installation in the context of sustainable development of construction
}

\author{
Robert Kruzel $^{1}$, Pawet Helbrych ${ }^{1, *}$ \\ ${ }^{1}$ Faculty of Civil Engineering, Czestochowa University of Technology, Poland
}

\begin{abstract}
The article presents the general problem of sustainable development of construction in Poland. The principles of photovoltaic cell operation are discussed depending on the type of panels used. The issue of efficiency is presented on the example of a single cell. The article presents currently available photovoltaic systems, their construction and ways of connecting solar modules. The aim of the study is to analyse the profitability of a photovoltaic installation for individual energy consumers on the example of a household located in an energy district in central Poland. In addition, boundary conditions justifying the economic basis for the construction of photovoltaic power plants producing energy for the own needs of customers have been specified. As a research method, a standard cash flow model was adopted for an investment project consisting in the construction of a photovoltaic installation. The revenues are avoided costs of purchase and distribution of electricity through the production of electricity from PV for the own needs of consumers.
\end{abstract}

\section{Introduction}

The technology is currently developing dynamically; it affects all aspects of human life and the efficiency of using renewable energy sources. For many years solar radiation has been one of the most common factors used to produce energy. In Poland, there is a decline in investments in wind farms, which is a consequence of the law introduced on 16 July 2016 in this respect, investors associated with the renewable energy industry are increasingly willing to transfer their capital into photovoltaic projects [1-4].

At the end of 2017, the photovoltaic potential in Poland is more than 480 photovoltaic installations with a total power capacity of over $107 \mathrm{MW}$, licensed by the Energy Regulatory Office and 28,500 prosumer microfilm installations with a power capacity up to $40 \mathrm{~kW}$, whose total installed power capacity was $182.5 \mathrm{MW}$. Almost all micro-installations in Poland are photovoltaic installations [1-4].

Figure 1 presents the development of photovoltaic installations licensed by the Energy Regulatory Office (ERO) and micro-installations, since 2008 to the end of 2017.

\footnotetext{
*Corresponding author: phelbrych@bud.pcz.pl
} 


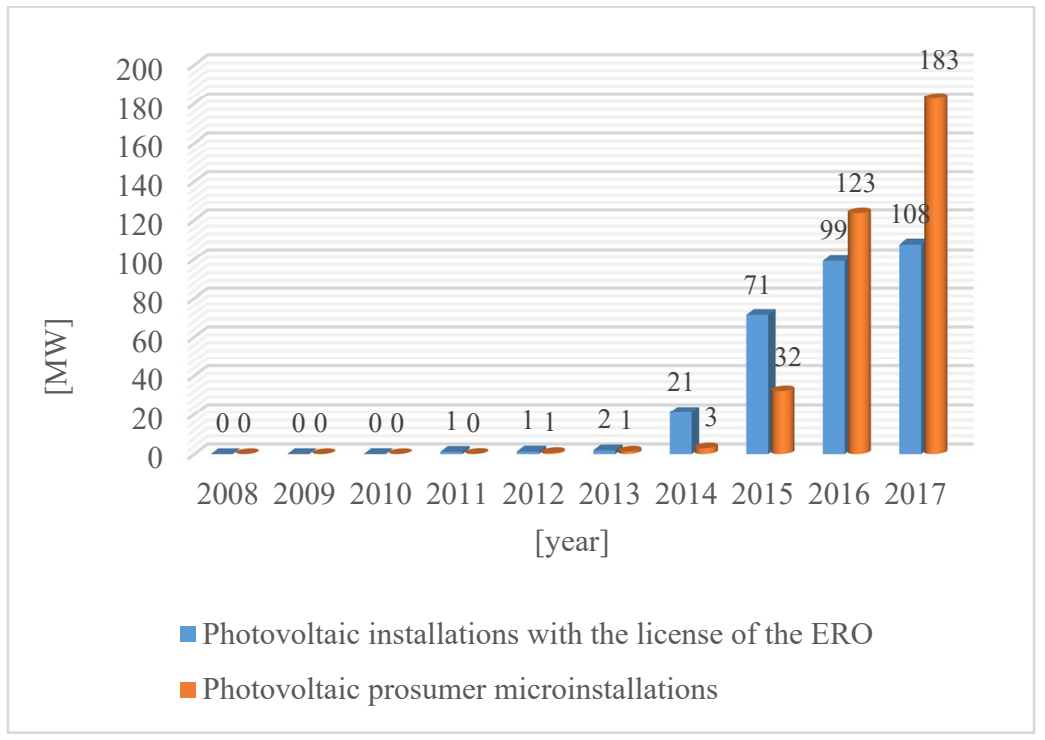

Fig. 1. Energy produced in Poland by photovoltaic installations in 2008-2017 [1-2].

\section{Description of the construction of a typical solar photovoltaic installation}

The micro-installation in accordance with the Polish law of 20 February 2015 is a renewable energy installation with a total installed electrical power of no more than $40 \mathrm{~kW}$, connected to the power grid with a rated voltage of less than $110 \mathrm{kV}$.

The prosumer according to the Polish law of June 22, 2016 is the final consumer purchasing electricity on the basis of a complex contract, producing electricity only from renewable energy sources in micro-installations for its own consumption, not related to the business [1-4].

A typical photovoltaic micro-installation in Poland is made of photovoltaic panels. Almost all micro-installations in Poland are photovoltaic installations. Photovoltaic panels are made of individual photovoltaic cells, which generate electrical voltage when exposed to solar radiation. Individual photovoltaic cells are usually made of selenium, silicon, germanium, which are semiconductor materials. Currently, three generations of photovoltaic cells are available, differing in their structure, materials they are made of and efficiency. Table 1 presents three generations of photovoltaic cells [1-4].

Table 1. Three generations of single photovoltaic cells - properties [1-4].

\begin{tabular}{|c|c|c|c|}
\hline Generation & Specification & Signature & Efficiency \\
\hline \multirow{3}{*}{ I } & \multirow{3}{*}{$\begin{array}{l}\text { Monocrystalline cells (sc-Si), polycrystalline cells } \\
\text { (mc-Si), multi-junction cells (mj-cells). Used in space } \\
\text { techniques. High material costs. }\end{array}$} & mj-cells & $30-43 \%$ \\
\hline & & $\mathrm{sc}-\mathrm{Si}$ & $14-22 \%$ \\
\hline & & $\mathrm{mc}-\mathrm{Si}$ & $13-18 \%$ \\
\hline \multirow{4}{*}{ II } & \multirow{4}{*}{$\begin{array}{l}\text { Thin-layer cells from amorphous silicon (a-Si), } \\
\text { cadmium telluride thin-film cells (Cd-Te), thin-film } \\
\text { cells made of a mixture of copper, gallium, selenium, } \\
\text { indium (CIGS) }\end{array}$} & $\mathrm{a}-\mathrm{Si}: \mathrm{H}$ & $6-9 \%$ \\
\hline & & $\mu \mathrm{c}-\mathrm{Si}$ & $6-11 \%$ \\
\hline & & CdTe & $9-11 \%$ \\
\hline & & $\mathrm{CI}(\mathrm{G}) \mathrm{S}$ & $10-12 \%$ \\
\hline \multirow{2}{*}{ III } & \multirow{2}{*}{$\begin{array}{l}\text { Dye cells. Operation based on artificial synthesis. } \\
\text { (DSSC) }\end{array}$} & DSSC & $12.3 \%$ \\
\hline & & oSC & $4-6 \%$ \\
\hline
\end{tabular}


A typical solar micro-installation installation in Poland is constructed from a single module or several photovoltaic modules connected to each other. The modules are connected in series, creating a "string", which increases the sumeric voltage. To obtain a high value of the output current, individual string should be connected in parallel to form a solar array. Power conditions output of individual solar modules does exceed $250 \mathrm{Wp}-$ peak power watts. Watt Peak power is the power supplied by the modules at an irradiance instead of $1000 \mathrm{~W} / \mathrm{m}^{2}$ and the module temperature of $25^{\circ} \mathrm{C}$. In practice, photovoltaic cells, for the most part of their operational life, work in varying atmospheric conditions, and variable solar power, which affects more than the theoretical production of electricity. It affects the production of electric energy, the reflection's angle of solar radiation and the drop in voltage on the wires in the inverter and other elements of the installation. Total losses in the production of electricity in photovoltaic micro-installations in relation to power conditions declined as $250 \mathrm{Wp}$ - is around $25 \%$. A higher temperature than the optimal temperature $\left(25^{\circ} \mathrm{C}\right)$ reduces the conversion efficiency. This reduction depends directly on the type of material used for the PV cells production. It is estimated that excessive heating of PV cells in micro-installations may lead to a decrease in efficiency of panels by $0.5 \% / 1^{\circ} \mathrm{C}$. The importance of achieving optimum efficiency of energy generation in solar installations of the prosumer has their correct location. Orient PV module towards the Sun. Figure 2 shows the areas of insolation in Poland [1-6].

Figure 3 shows a construction of a typical photovoltaic micro-installation in Poland.

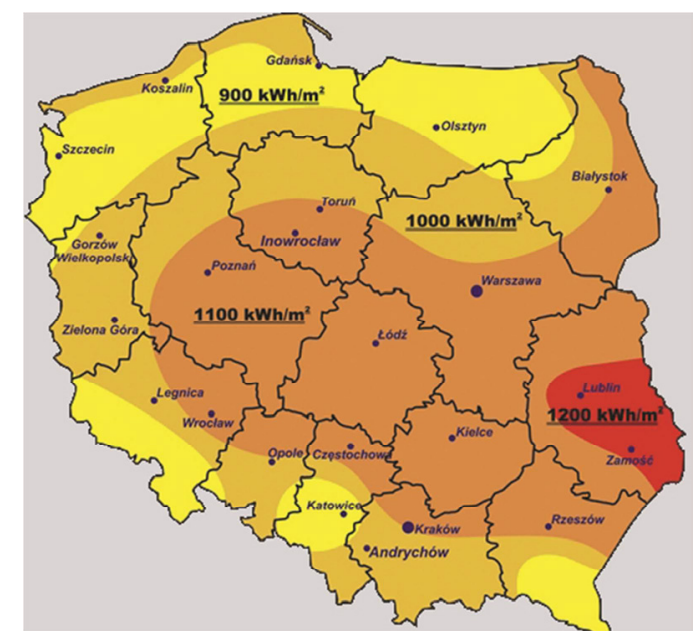

Fig. 2. Areas of insolation in Poland [5].

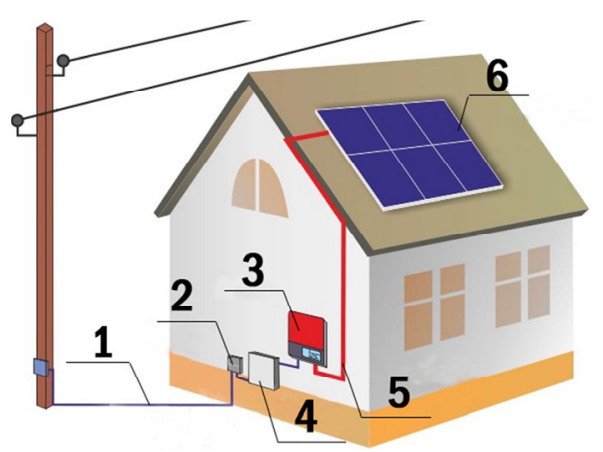

Fig. 3. Construction of a typical photovoltaic micro-installations in Poland: $1-$ power cable, 2 - energy meter, 3 - inverter, 4 - main switchboard, 5-DC wire, 6- photovoltaic panel [6]. 


\section{The efficiency of an individual photovoltaic cell}

Photon energy can be expressed by the formula:

$$
E=h f
$$

The wave with the length $\lambda$, moving with the speed $v$ has the frequency expressed by the dependence:

$$
f=\frac{v}{\lambda}
$$

The energy of solar radiation can be described by the dependence:

$$
E=h f=\frac{h v}{\lambda}=\frac{1,24}{\lambda}
$$

Designations for designs (1-3):

$E$ - photon energy, [eV],

$h-$ Planck's constant $=6,6256 \cdot 10^{-34},[\mathrm{~J} \cdot \mathrm{s}]$,

$f$-photon frequency, [Hz],

$v$ - wave speed, $[\mathrm{m} / \mathrm{s}]$,

$\lambda$ - wavelength, $[\mu \mathrm{m}]$.

Photocell efficiency can be expressed by the formula:

$$
\eta=\frac{I_{S C} \cdot V_{O C} \cdot F F}{E \cdot S} \cdot 100 \%
$$

where:

$I_{S C}-$ short circuit current, [A],

$V_{O C}-$ open circuit voltage, [V],

$F F$ - characteristic fill rate,

$S$ - photocell surface, $\left[\mathrm{m}^{2}\right]$,

$E$ - sunlight irradiance, $\left[\mathrm{W} / \mathrm{m}^{2}\right]$.

The characteristic fill rate is the ratio of the current determined to the area under the characteristic of the device and is determined with the formula:

$$
F F=\frac{I_{m p p} \cdot V_{m p p}}{I_{S C} \cdot V_{O C}}
$$

where:

$I_{m p p}$ - Maximum Power Point current, [A],

$V_{m p p}$ - Maximum Power Point voltage, [V].

Using the above formulas, it is possible to calculate the efficiency of the example photocell LG270S1C-A3, with an area of $12.5 \times 12.5 \mathrm{~cm}$. Figure 4 shows the characteristic card of an example photovoltaic cell [7-8]. 
Electrical Properties (NOCT*)

\begin{tabular}{lcccc}
\hline & LG270S1C-A3 & LG265S1C-A3 & LG260S1C-A3 \\
\hline Maximum power (Pmpp) & 198 & 195 & 191 \\
\hline MPP voltage (Vmpp) & 29.0 & 28.8 & 28.6 \\
\hline MPP current (Impp) & 6.84 & 6.77 & 6.68 \\
\hline Open circuit voltage (Noc) & 35.7 & 35.5 & 35.3 \\
\hline Short circuit current (lsc) & 7.39 & 7.34 & 7.29 \\
\hline $\begin{array}{l}\text { Efficiency reduction } \\
\left.\text { (from 1000 } \mathrm{W} / \mathrm{m}^{2} \text { to 200 } \mathrm{W} / \mathrm{m}^{2}\right)\end{array}$ & & $<4.5 \%$ & \\
\hline
\end{tabular}

- NOCT (Nominal Operating Cell Temperature): Irradiance $800 \mathrm{~W} / \mathrm{m}^{2}$, ambient temperature $20 \mathrm{CC}^{\text {, }}$ wind speed $1 \mathrm{~m} / \mathrm{s}$

Fig. 4. Photocell data sheet information LG270S1C-A3 [7].

The calculations assumed at Nominal Operating Cell Temperature (NOCT) conditions [8]:

- Sunlight irradiance $800 \mathrm{~W} / \mathrm{m}^{2}$,

- Ambient temperature of the panel $+20^{\circ} \mathrm{C}$,

- Spectrum of radiation for atmosphere density 1.5 (AM1,5),

- Wind speed $1 \mathrm{~m} / \mathrm{s}$.

Using the formulas 4 and 5 the numbers in Figure 4, we get the dependence:

$$
\eta=\frac{7,39 \cdot 35,7 \cdot 0,75}{800 \cdot 0,015625} \cdot 100 \%=15,83 \%
$$

Efficiency of the example photocell LG270S1C-A3, in the assumed operating conditions, a value of $15.83 \%$.

\section{Analysis of the profitability of photovoltaic micro-installations}

The investment in the photovoltaic micro-installations may bring many benefits to the environment, and contribute to reducing the emission of harmful gases to the atmosphere and to the sustainable development of the economy. The economic profit of this type of investment depends on many factors. The investor wants a situation where the energy produced for its own needs, including investment and operational costs, is not more expensive than the energy bought from the energy distributor, and all produced electricity is consumed for the investor's own needs [9-11].

The analysis of the economic profitability of the photovoltaic micro-installation was made with the assumptions of the cash flow model for the classical investment project for the existing micro-installation, located on a single-family building located in the vicinity of the city of Bełchatów, in Poland [9-11].

\subsection{Assumptions for analysis}

An investment in a photovoltaic micro-installation is an investment in a fixed asset that brings revenues to the investor throughout the investment period of 25 years.

he analysis assumes:

- revenues are avoided gross costs of network charges, costs of electricity, which has been replaced by energy produced in the plumbing micro-installation,

- avoiding 23\% VAT on consumed electricity,

- no costs due to the registration of the photovoltaic installation to the ERO due to the lack of a license for $40 \mathrm{kV}$ pro-ecological micro-installations, 
- investment costs of CAPEX (capital expenditures) as gross costs.

Current costs of the solar micro-installation:

- a micro-installation is maintenance-free, while the investor pays only the costs of cleaning solar panels, which amount to 0.5\% CAPEX (O\&M costs),

- insurance - $0.5 \%$ CAPEX,

- the investor is also the owner of the property on which the micro-installation is located, does not bear the costs of renting the roof and property tax,

- currently the manufacturer's warranty for inverters is for a period of 10 years, therefore it is necessary to replace this device after 10 years, the current technological development in the photovoltaic industry, allows the assumption that the purchased new inverter will have a 15 -year warranty.

The macroeconomic assumptions, the duration of the investment from 2017 to 2042, include:

- inflation,

- exchange rate,

- increase in electricity prices and distribution.

The values of individual macroeconomic assumptions are summarized in Table 2.

Table 2. Macroeconomic assumptions [own work].

\begin{tabular}{|c|c|c|c|c|c|c|}
\hline \multicolumn{7}{|c|}{ Macroeconomic assumptions } \\
\hline \multicolumn{2}{|c|}{} & $\mathbf{2 0 1 7}$ & $\mathbf{2 0 1 8}$ & $\mathbf{2 0 2 0}$ & $\mathbf{2 0 2 1}$ & $\mathbf{2 0 2 2 - 2 0 4 2}$ \\
\hline Exchange rate & PLN/EUR & 4.1 & 4.2 & 4.1 & 4.0 & 3.8 \\
\hline Inflation & $\%$ & 2.1 & 2.7 & 3.0 & 2.6 & 2.6 \\
\hline Electricity price increase & $\%$ & 2.0 & 3.0 & 2.5 & 2.5 & 2.5 \\
\hline Distribution prices increase & $\%$ & 2.0 & 3.0 & 2.5 & 2.5 & 2.5 \\
\hline
\end{tabular}

Investment assumptions on the example of existing micro-installation commissioned in November 2016:

- CAPEX investment costs of PLN 25,000 gross (EUR 6,250) for a $4 \mathrm{~kW}$ microinstallation. The CAPEX component costs include: photovoltaic panels, inverter, DC and AC cables, design, construction, DC and AC protection switchgear, reconciliations,

- location of the analysed micro-institution - around the city of Bełchatów, Poland,

- no subsidy or other financial support, pure economic model,

- $3 \%$ decrease in the efficiency of the installation in the first year of work and $0.6 \%$ decrease in efficiency in each subsequent year,

- assumption of insolation in accordance with Figure 2,

- micro-installation installed on a single-family house with a usable area of approx. $175 \mathrm{~m}^{2}$, 16 panels of $250 \mathrm{~W}$. House inhabited by 4 adults, heating - from a pellet stove,

- the current average energy consumption is about $3,120 \mathrm{kWh} /$ year, it was assumed that the average annual consumption of electricity in the household will be constant.

Financial assumptions:

- own contribution - $100 \%$,

- debt share $-0 \%$,

- the average sale price of electricity was set in accordance with the supplier's price list in the analysed region - PLN $0.30 / 1 \mathrm{~kW}$,

- the average price of distribution fees was adopted in accordance with the supplier's price list in the analysed region - PLN $0.27 / 1 \mathrm{~kW}$,

- the average price of fixed fees was adopted in accordance with the supplier's price list in the analysed region - PLN 19.90 / 1 month. 


\section{Results}

The analysis is based on data read from the measuring devices of the photovoltaic microinstallation. Figure 5 shows the daily electricity production diagrams on 30.07.2017.

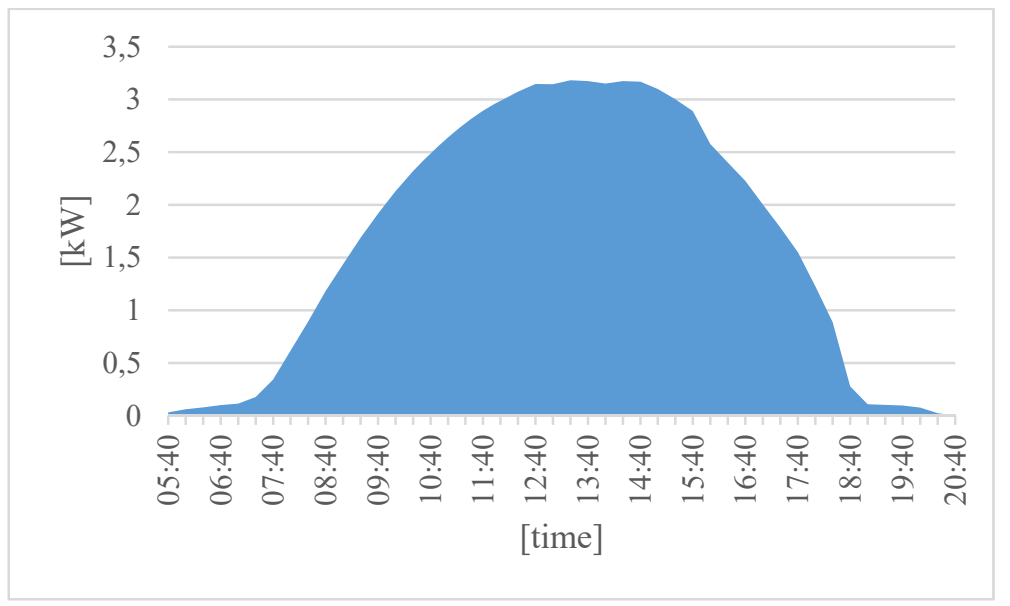

Fig. 5. Daily energy production on 30.07.2017 [own work].

The graph in Figure 5 shows that a significant value of electricity production (over $1 \mathrm{~kW}$ ) starts from 8.40 and lasts until 18.20. The maximum value of electricity production is at 3:00 PM and amounts to $3.1 \mathrm{~kW}$.

In the summer months in Poland, the production of energy in micro-installations is the largest. In 2017, the most energy in this micro-installation was produced in July. Figure 6 shows energy production divided into days. Figure 7 presents the production of electricity in micro-installation in 2017, divided into individual months.

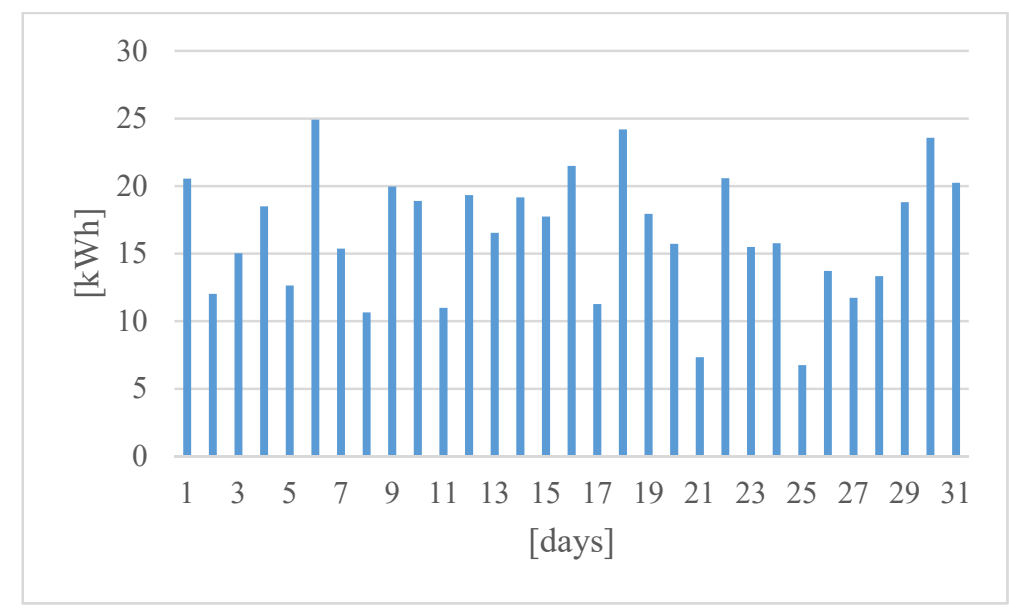

Fig. 6. Energy production in the solar micro-installation in July 2017 [own work]. 


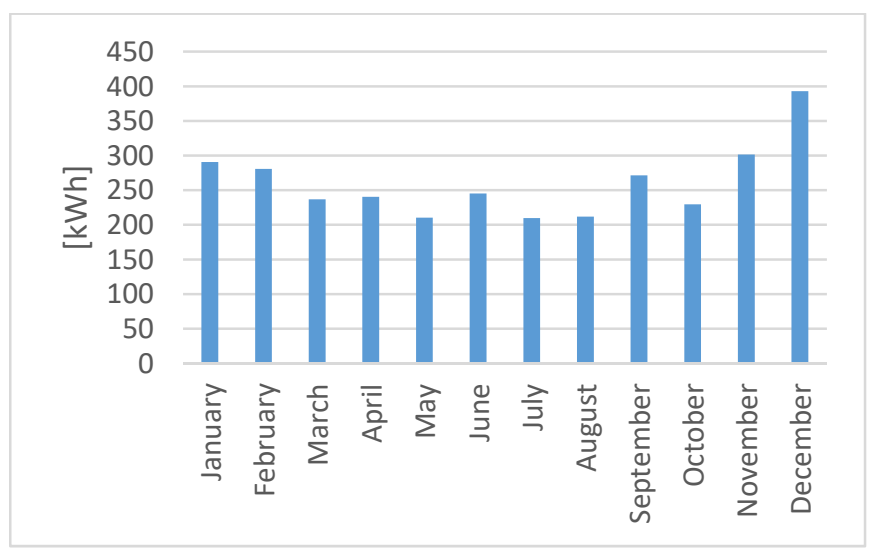

Fig. 7. Energy consumption plot in the solar micro-installation in 2017 [own work].

Figure 8 presents an annual statement of production, consumption and energy delivered to the power grid.

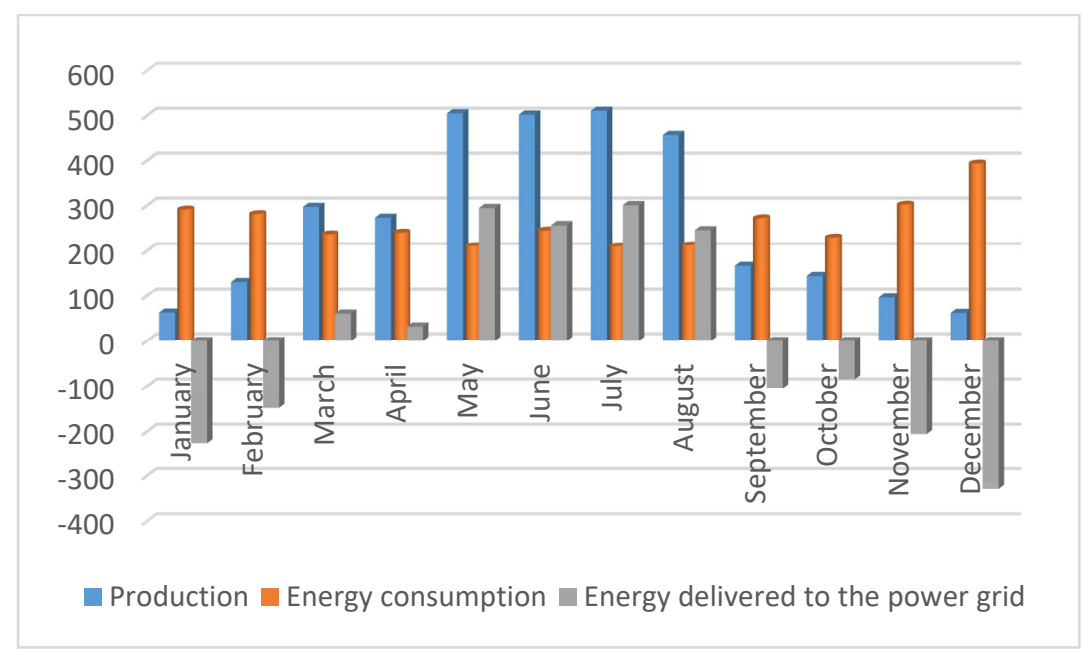

Fig. 8. Production, consumption and energy delivered to the power grid in 2017 [own work].

The total energy produced in the tested pro-solar micro-installation is $3,206.96 \mathrm{kWh}$, the energy consumed amounts to $3,121.08 \mathrm{kWh}$. In months such as: January, February, September, October, November, December, the energy consumption of the household exceeded the amount of energy produced. The distributor of energy in the region in which the prospective photovoltaic micro-installation is located allows the payment for energy in two 6-month periods. The first accounting period is from January 1st to June 30th, and the second accounting period is from July 1 st to December 31 st. In the first settlement period, the investor produced $1,641.39 \mathrm{kWh}$ (including multiplying cumulated energy by 0.8 set by the legislator) and consumed $1,504.19 \mathrm{kWh}$. In the first settlement period, the investor incurred only fixed and distribution fees, and to the next accounting period brought an energy allowance in the amount of $137.2 \mathrm{kWh}$.

The investor in the second trading period produced $905.92 \mathrm{kWh}$ (including multiplying cumulated energy by 0.8 set by the legislator) and used $1,616.89 \mathrm{kWh}$, taking into account the energy allowance from the first settlement period, the investor had to pay for $573.77 \mathrm{kWh}$ of energy and pay the cost of fixed and distribution fees. 


\subsection{Cost-effectiveness analysis}

In the Table 3 is analysis of the profitability of a photovoltaic micro-installation.

Table 3. Profitability analysis of a photovoltaic micro-installation [own work].

\begin{tabular}{|c|c|c|c|c|c|c|c|c|c|}
\hline & 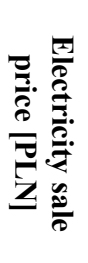 & 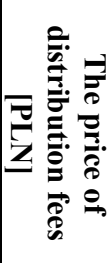 & 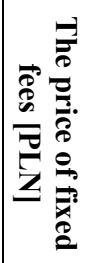 & $\begin{array}{l}0 \\
\& \\
\underline{\mathbf{S}} \\
\mathbf{\Sigma}\end{array}$ & 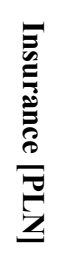 & 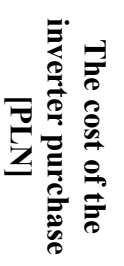 & 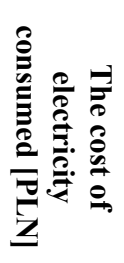 & 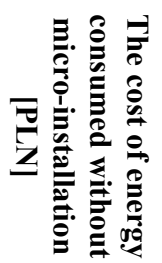 & 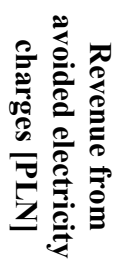 \\
\hline 2018 & 0.30 & 0.27 & 20 & 125 & 125 & 0 & 489 & 2017 & 1528 \\
\hline 2019 & 0.32 & 0.29 & 20 & 128 & 128 & 0 & 502 & 2125 & 1623 \\
\hline 2020 & 0.33 & 0.30 & 21 & 132 & 132 & 0 & 517 & 2236 & 1718 \\
\hline 2021 & 0.35 & 0.32 & 22 & 136 & 136 & 0 & 531 & 2343 & 1813 \\
\hline 2022 & 0.37 & 0.33 & 22 & 139 & 139 & 0 & 545 & 2457 & 1912 \\
\hline 2023 & 0.39 & 0.35 & 23 & 143 & 143 & 0 & 559 & 2575 & 2016 \\
\hline 2024 & 0.41 & 0.37 & 23 & 147 & 147 & 0 & 573 & 2700 & 2126 \\
\hline 2025 & 0.43 & 0.39 & 24 & 150 & 150 & 0 & 588 & 2830 & 2242 \\
\hline 2026 & 0.45 & 0.41 & 25 & 154 & 154 & 0 & 603 & 2968 & 2364 \\
\hline 2027 & 0.47 & 0.43 & 25 & 158 & 158 & 0 & 619 & 3111 & 2492 \\
\hline 2028 & 0.50 & 0.45 & 26 & 162 & 162 & 3750 & 4385 & 3263 & -1123 \\
\hline 2029 & 0.52 & 0.47 & 27 & 167 & 167 & 0 & 652 & 3421 & 2769 \\
\hline 2030 & 0.55 & 0.50 & 27 & 171 & 171 & 0 & 669 & 3588 & 2919 \\
\hline 2031 & 0.58 & 0.52 & 28 & 175 & 175 & 0 & 686 & 3763 & 3076 \\
\hline 2032 & 0.61 & 0.55 & 29 & 180 & 180 & 0 & 704 & 3946 & 3242 \\
\hline 2033 & 0.64 & 0.57 & 29 & 185 & 185 & 0 & 722 & 4139 & 3416 \\
\hline 2034 & 0.67 & 0.60 & 30 & 189 & 189 & 0 & 741 & 4341 & 3600 \\
\hline 2035 & 0.71 & 0.63 & 31 & 194 & 194 & 0 & 760 & 4553 & 3793 \\
\hline 2036 & 0.74 & 0.67 & 32 & 199 & 199 & 0 & 780 & 4776 & 3996 \\
\hline 2037 & 0.78 & 0.70 & 33 & 205 & 205 & 0 & 800 & 5010 & 4210 \\
\hline 2038 & 0.82 & 0.74 & 33 & 210 & 210 & 0 & 821 & 5256 & 4435 \\
\hline 2039 & 0.86 & 0.77 & 34 & 215 & 215 & 0 & 843 & 5514 & 4672 \\
\hline 2040 & 0.90 & 0.81 & 35 & 221 & 221 & 0 & 865 & 5785 & 4921 \\
\hline 2041 & 0.95 & 0.86 & 36 & 227 & 227 & 0 & 887 & 6070 & 5183 \\
\hline 2042 & 1.00 & 0.90 & 37 & 233 & 233 & 0 & 910 & 6368 & 5458 \\
\hline
\end{tabular}

\section{Conclusions}

For the tested solar installation, total revenue in assumed the exploitation period will amount to PLN 74,403. The reimbursement of costs incurred for the investment, taking into account the assumed costs as well as the fixed and operational fees, will take place approximately 12 years after commissioning the installation what is presented in Fig. 8. 


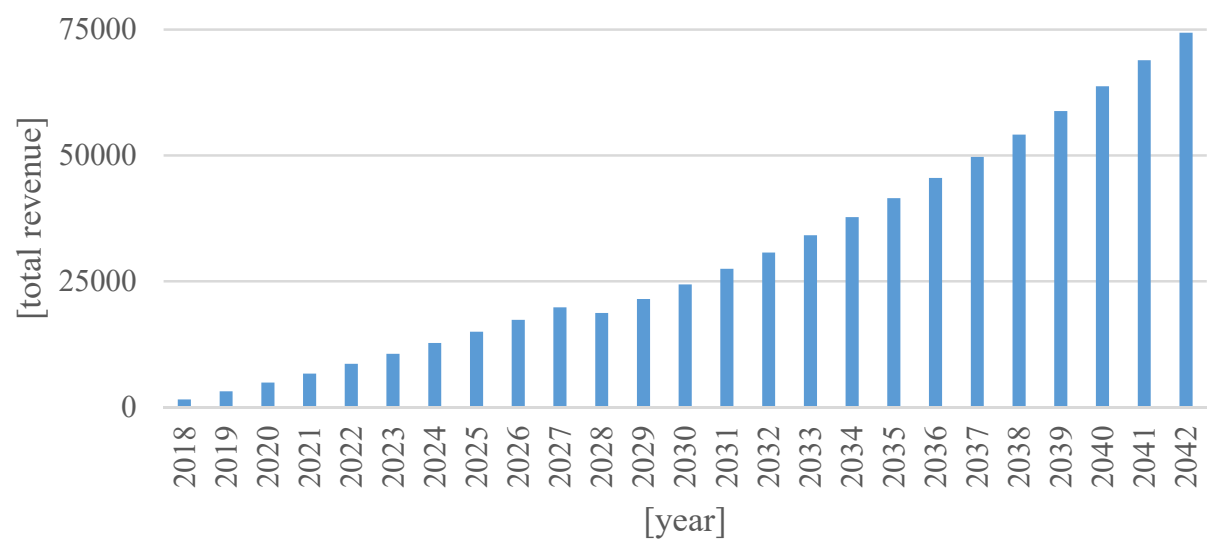

Fig. 9. Total earnings due to avoided charges for electricity [own work].

Photovoltaic micro-installations can already be profitable in Poland without a subsidy system. The rapid development of this technology allows us to claim that with the passage of time, the period of return of investment costs incurred will be shortened.

To determine the profitability of using photovoltaic micro-installations, it is necessary to know the prosumers long-term sun exposure in a given area. Insolation for Poland is on average 1600 hours/year. It is forecasted that in Poland, the number of sunny days, together with global climate change, will increase it up to 2000 hours/year, which will significantly affect the cost-effectiveness of photovoltaic installations.

\section{References}

1. www.ure.gov.pl

2. www.gramwzielone.pl

3. Ustawa z dnia 20 lutego 2015 r. o odnawialnych źródłach energii (Dz.U. 2015 poz. 478)

4. Ustawa z dnia 22 czerwca 2016 r. o zmianie ustawy - Prawo zamówień publicznych (Dz.U. 2016 poz. 1020)

5. www.dobraenergia.edu.pl

6. www.solgen.pl

7. www.solarelectricsupply.com

8. B. Caran, R. Szczerbowski, Zeszyty Naukowe Instytutu Gospodarki Surowcami Mineralnymi i Energią Polskiej Akademii Nauk, 98, 15-26 (2017)

9. M. Chmieliński, Profitability analysis of photovoltaic micro-installation in Poland based on electrical energy production for own use, Economics of the $21^{\text {st }}$ century, 3(7) (2015)

10. H. D. Stryczewska, Energie odnawialne: przeglad technologii $i$ zastosowań, (Politechnika Lubelska, Lublin 2012)

11. M. Bruch, M. Müller, Calculation of the Cost Effectiveness of a PV Battery System, Energy Procedia 46, 262-270 (2014) 